University of Nebraska - Lincoln

DigitalCommons@University of Nebraska - Lincoln

2012

\title{
Amorphous Hf-based foams with aligned, elongated pores
}

Marie E. Cox

Northwestern University

Laszlo J. Kecskes

U.S. Army Research Laboratory

Suveen N. Mathaudhu

U.S. Army Research Office

David C. Dunand

Northwestern University, dunand@northwestern.edu

Follow this and additional works at: https://digitalcommons.unl.edu/usarmyresearch

Cox, Marie E.; Kecskes, Laszlo J.; Mathaudhu, Suveen N.; and Dunand, David C., "Amorphous Hf-based foams with aligned, elongated pores" (2012). US Army Research. 192.

https://digitalcommons.unl.edu/usarmyresearch/192

This Article is brought to you for free and open access by the U.S. Department of Defense at DigitalCommons@University of Nebraska - Lincoln. It has been accepted for inclusion in US Army Research by an authorized administrator of DigitalCommons@University of Nebraska - Lincoln. 
Rapid communication

\title{
Amorphous Hf-based foams with aligned, elongated pores
}

\author{
Marie E. Cox ${ }^{\mathrm{a}}$, Laszlo J. Kecskes ${ }^{\mathrm{b}}$, Suveen N. Mathaudhu ${ }^{\mathrm{c}}$, David C. Dunand ${ }^{\mathrm{a}, *}$ \\ a Department of Materials Science and Engineering, Northwestern University, Evanston, IL 60208, USA \\ ${ }^{\mathrm{b}}$ Weapons and Materials Research Directorate, U.S. Army Research Laboratory, Aberdeen Proving Ground, MD 21005, USA \\ ${ }^{c}$ Materials Science Division, U.S. Army Research Office, Research Triangle Park, NC 27709, USA
}

\section{A R T I C L E I N F O}

\section{Article history:}

Received 20 April 2011

Received in revised form 3 November 2011

Accepted 13 November 2011

Available online 22 November 2011

\section{Keywords:}

Bulk amorphous alloy

Cellular materials

Porous materials

Equal channel angular processing

Hafnium-based glassy alloy

\begin{abstract}
A B S T R A C T
Warm equal channel angular extrusion is used to consolidate a blend of amorphous $\mathrm{Hf}_{44.5} \mathrm{Cu}_{27} \mathrm{Ni}_{13.5} \mathrm{Ti}_{5} \mathrm{Al}_{10}$ and crystalline $\mathrm{W}$ powders. Dissolution of the $\mathrm{W}$ phase results in $\sim 60 \%$ aligned, elongated pores within an amorphous Hf-based matrix exhibiting ductility in compression, but at lower strengths than similar amorphous $\mathrm{Zr}$-based foams due to incomplete bonding between Hf-based powders.
\end{abstract}

(c) 2011 Elsevier B.V. All rights reserved.
Hf-based bulk metallic glass (BMG) alloys were originally investigated for use as kinetic energy penetrator materials [1,2]. Typically, in compression, BMGs deform by shear localization [3] leading to a self-sharpening behavior, desirable in ballistic materials [4]. Hafnium was substituted for zirconium in wellstudied Zr-based BMG alloy to increase the density of the alloy for improved ballistic performance [1]. Aside from the greater kinetic energy associated with the higher mass density of the Hf-based $\mathrm{BMG}$, there is the additional benefit of a higher fracture strength: $2150 \mathrm{MPa}$ for $\mathrm{Hf}_{52.5} \mathrm{Cu}_{17.9} \mathrm{Ni}_{14.6} \mathrm{Al}_{10} \mathrm{Ti}_{5}$ as compared to $<1800 \mathrm{MPa}$ for $\mathrm{Zr}_{52.5} \mathrm{Cu}_{17.9} \mathrm{Ni}_{14.6} \mathrm{Al}_{10} \mathrm{Ti}_{5}$ [2].

The intrinsic brittleness of BMGs is due to shear band localization and can be alleviated by arresting shear bands $[5,6]$. Two well-studied approaches are based on the addition of a ductile metallic crystalline second phase [7,8] or pores [9-11]. Porous BMGs are much weaker than their dense counterparts, but have much higher compressive ductility [12-14] with non-catastrophic damage accumulation [15]. Most current BMG foams were created by liquid state processing, e.g., by infiltration of a temporary space-holder phase [14,16], expansion of entrapped gas in the liquid phase $[17,18]$ or in the undercooled liquid region $[19,20]$. These liquid routes become difficult with Hf-based BMGs which have lower glass forming abilities and higher melting temperatures than their Zr-based BMG counterparts [2,21]. Hf-based BMGs composites created by infiltration of tungsten wire performs with liquid

\footnotetext{
* Corresponding author. Fax: +1 8474917820.

E-mail address: dunand@northwestern.edu (D.C. Dunand).
}

$\mathrm{Hf}_{52.5} \mathrm{Cu}_{17.9} \mathrm{Ni}_{14.6} \mathrm{Al}_{10} \mathrm{Ti}_{5}$ at 1065 and $950{ }^{\circ} \mathrm{C}$ (above and below the liquidus temperature of $1050^{\circ} \mathrm{C}$ ) showed formation of undesirable intermetallic phases with the $\mathrm{W}$ fibers and the stainless steel crucible, resulting in varying degrees of devitrification in the BMG [22]. These processing difficulties are probably an important reason why liquid infiltration methods to fabricate Hf-based composites have not been widely investigated to date.

Amorphous powder densification is a solid-state processing method for creating bulk and reinforced BMGs that circumvent the aforementioned issues associated with the liquid route [23]. In this method, densification occurs in the supercooled region of the BMG powders, which is significantly below the melting temperature. In particular, equal channel angular extrusion (ECAE) is an attractive method to densify BMG powders with and without a second phase [24-27], because the cross-section of the specimen is not altered during densification. Previously, BMG/metal composites, created by ECAE of Zr-based alloys [28], hot pressing of Cu-based [29] or $\mathrm{Zr}$-based [30] alloys and warm-extrusion of Ni-based alloys [31], have been processed into foams by selective dissolution of the crystalline metallic space-holder. Selective dissolution has also been performed on a hot pressed Zr-based BMG containing a salt spaceholder [32]. ECAE and warm extrusion techniques create pores which are usually elongated since they replicate the shape of the ductile space-holders deformed during the densification step. Here, for the first time, we use warm ECAE densification of composites followed by space-holder dissolution to create porous Hf-based BMGs.

ARLloy\#1, an alloy with a nominal composition of $\mathrm{Hf}_{44.5} \mathrm{Cu}_{27} \mathrm{Ni}_{13.5} \mathrm{Ti}_{5} \mathrm{Al}_{10}$ (at.\%) (or $\mathrm{Hf}_{72.47} \mathrm{Cu}_{15.65} \mathrm{Ni}_{7.23} \mathrm{Ti}_{2.18} \mathrm{Al}_{2.46}$ 
(wt.\%), referred to as ARLloy hereafter), was atomized into 38-105 $\mu \mathrm{m}$ powders by high pressure inert gas atomization at the Materials Processing Center of Ames Laboratory. These powders were mixed with 60 vol.\% tungsten powders (45-106 $\mu \mathrm{m}, 99.98 \%$ pure, from Alldyne Corp., Huntsville, AL). The powder blends were poured into nickel cans with $102 \mathrm{~mm}$ height, $25 \mathrm{~mm}$ diameter and $\sim 7 \mathrm{~mm}$ wall thickness, which were vacuum-sealed by electronbeam welding. The cans were then extruded at a rate of $0.635 \mathrm{~mm} / \mathrm{s}$ through a $90^{\circ} \mathrm{ECAE}$ die whose walls were heated to $530^{\circ} \mathrm{C}$, within ARLloy's supercooled liquid region $\left(T_{\mathrm{g}}=520^{\circ} \mathrm{C}, T_{\mathrm{X}}=560^{\circ} \mathrm{C}\right.$ [33] but well below its liquidus temperature $\left(T_{1}=990^{\circ} \mathrm{C}\right)$. After a single pass with no back-pressure, the consolidated composites were electro-discharge machined from the center of the extruded billet and polished into $2 \mathrm{~mm} \times 2 \mathrm{~mm} \times 4 \mathrm{~mm}$ compression samples, with their long dimension parallel to the direction of extrusion. An electrochemical cell with a $1.5 \mathrm{M} \mathrm{KOH}$ electrolyte, a voltage of $5.4 \mathrm{~V}$, a Ti-6Al-4V cathode, and agitated in an ultrasonic bath, was used for $20-23 \mathrm{~h}$ at ambient temperature to remove the $\mathrm{W}$ phase from these ARLloy/W composites.

The ARLloy/W composite and the resulting ARLloy foams were imaged using a Hitachi S-3400N-II SEM and optical microscopy. Porosities were measured by He pycnometry and the Archimedes method. Compressive properties of the ARLloy foams were determined by uniaxial compression in the direction of extrusion, under displacement control, at a nominal strain rate of $5 \times 10^{-4} \mathrm{~s}^{-1}$. Strain was measured by cross-head displacement, taking into account load train compliance determined on aluminum calibration samples before and after each test. X-ray diffraction using $\mathrm{Cu}-\mathrm{K} \alpha$ radiation was performed after mechanical testing to check for devitrification.

Optical microscopy of the composite polished cut surface parallel to the direction of extrusion shows extensive densification and deformation in both the ARLloy and $W$ phases (Fig. 1a). Alignment and co-deformation of the phases occurred along an angle of $\sim 23^{\circ}$ with respect to the extrusion direction, corresponding to the shear plane formed during ECAE [34]. After the removal of the $\mathrm{W}$ phase, scanning electron microscopy (SEM) micrographs of a bending fracture surface parallel to the direction of extrusion of the ARLloy foam (Fig. 1c) show deformation and good bonding of the ARLloy powders which are aligned in the shear direction; however, optical micrographs of a polished foam cross section show that individual powder particles are still visible (Fig. 1b). A crushed sample subjected to X-ray diffraction, confirmed that no significant devitrification occurred, or intermetallic phases formed, during the powder consolidation and that the $\mathrm{W}$ phase had been fully removed during dissolution (Fig. 2).

Previous work on Zr-based foams created by ECAE has shown that the degree of bonding between amorphous powders is sensitive to the ratio of flow strength between the crystalline and amorphous phases at the processing temperature [28]. Insufficient bonding between the BMG powders was observed when the crystalline space-holder phase (i.e., $\mathrm{Cu}$ or $\mathrm{Ni}$ ) was significantly weaker than the $\mathrm{Zr}$-based BMG powders $\left(\mathrm{Zr}_{58.5} \mathrm{Nb}_{2.8} \mathrm{Cu}_{15.6} \mathrm{Ni}_{12.8} \mathrm{Al}_{10.3}\right)$, and thus flowed around the strong BMG powders during extrusion, limiting their deformation and bonding to each other [25,28]. By contrast, when a $\mathrm{W}$ second phase was used at the processing temperature of $420^{\circ} \mathrm{C}$, both powders flowed and densified, resulting in a strong Zr-based BMG foam with elongated, aligned porosity, replicating the deformed $\mathrm{W}$ phase. The extent of deformation and bonding of the ARLloy powders in the present Hf-based BMG foams indicate that, at the extrusion rate and temperature used here, the ARLloy had a similar flow strength as W ( 320 MPa)[35].

Fig. 3 shows the engineering compressive stress-strain curves for two ARLloy foams (labeled 1 and 2) with porosity $p=64 \%$ and $62 \%$, respectively, whose structure is shown in Fig. 4 . The samples were loaded in the direction of extrusion, so the elongated pores
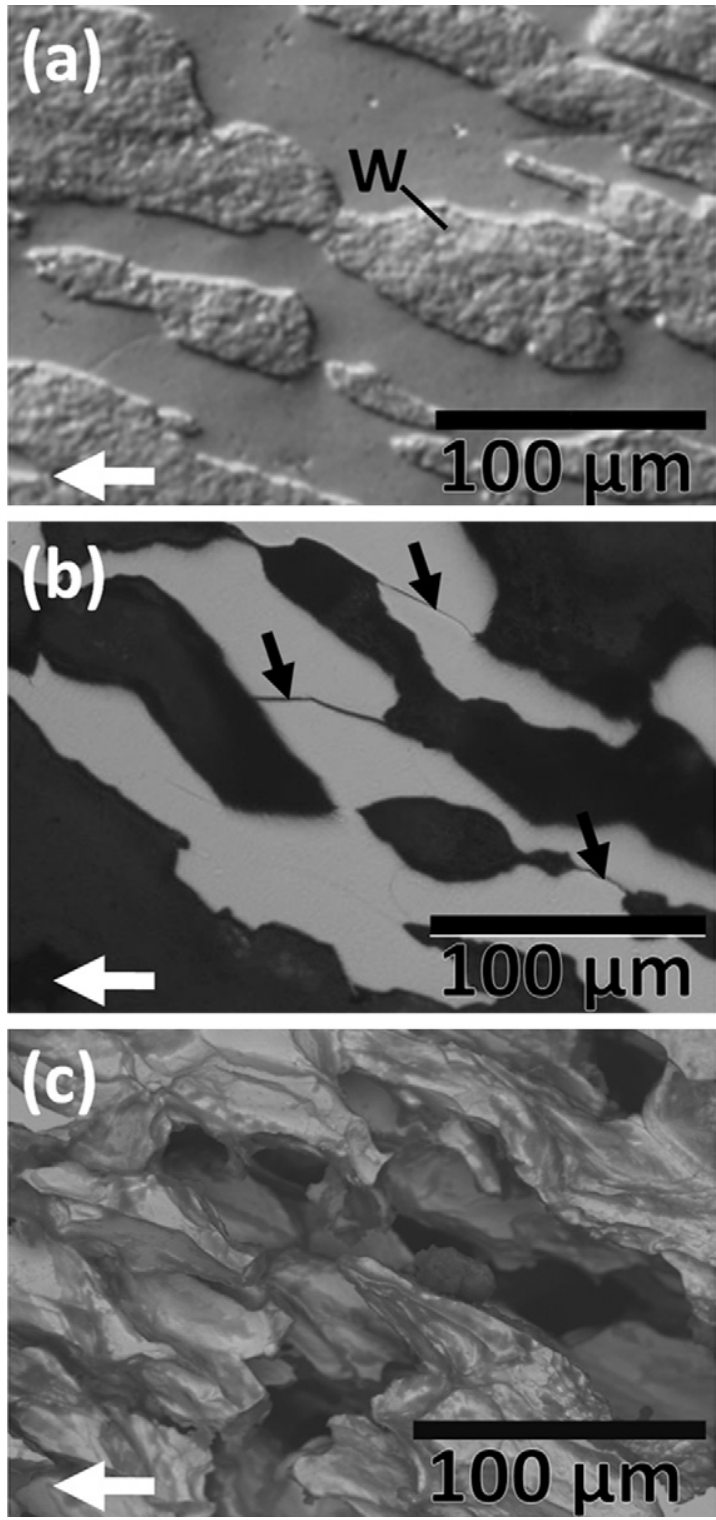

Fig. 1. Optical micrographs of cross-sections with the plane of polish parallel to the extrusion direction for (a) ARLloy-W composite; (b) ARLloy foam after W removal ( $\sim 64 \%$ porosity), with black arrows indicating cracks at prior powder boundaries; (c) SEM images of ARLloy foam sample 1 (64\% porosity) sample surface parallel to the direction of extrusion. White arrows indicate direction of extrusion.

were aligned $\sim 23^{\circ}$ with respect to the loading direction. The two foams exhibit a short elastic region terminated by a peak stresses of 11 and $16 \mathrm{MPa}$, respectively, followed by a large drop in stress and a long stress plateau at $\sim 2$ and $\sim 3 \mathrm{MPa}$, respectively. The lower stresses observed in sample 1 can be partially attributed to its higher porosity ( $p=64 \%$ compared to $62 \%$ ) and imperfect mixing of the powders may have lead to variations in local porosity and pore geometry within the sample resulting in stress concentrations. For sample 1 , the test was interrupted at $10 \%$ strain to image a crack, while for sample 2 , it was conducted up to the onset of densification at $\sim 65 \%$ strain, at which point the absorbed energy was $2.1 \mathrm{MJ} / \mathrm{m}^{3}$, as determined by integration of the stress-strain curve up to $65 \%$ strain. As observed previously in Zr-based BMG foams created by the same ECAE method [28], samples developed planar cracks at $22-26^{\circ}$ angles with respect to the loading axis (corresponding to the strut orientation and the shear planes created during ECAE) [34] between $5 \%$ and $9 \%$ strain. 


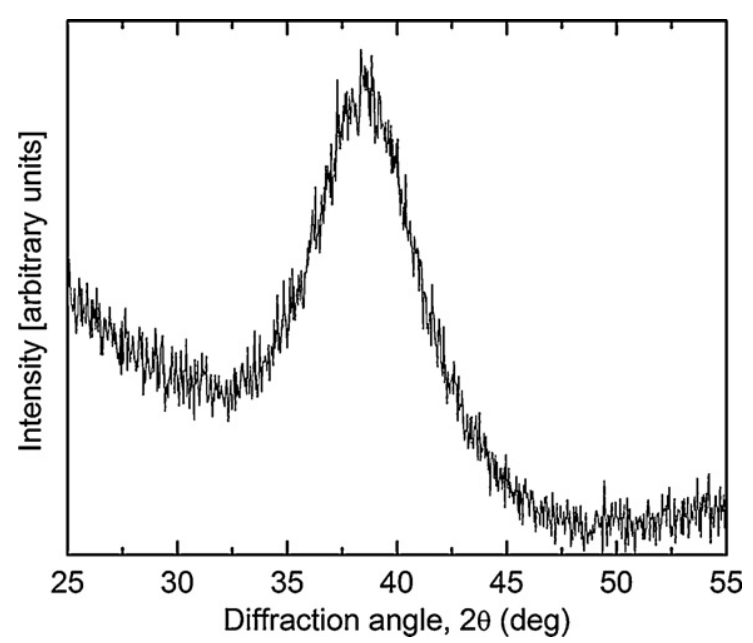

Fig. 2. XRD patterns of the ARLloy foam 2 showing a broad amorphous hump and no crystalline peaks.

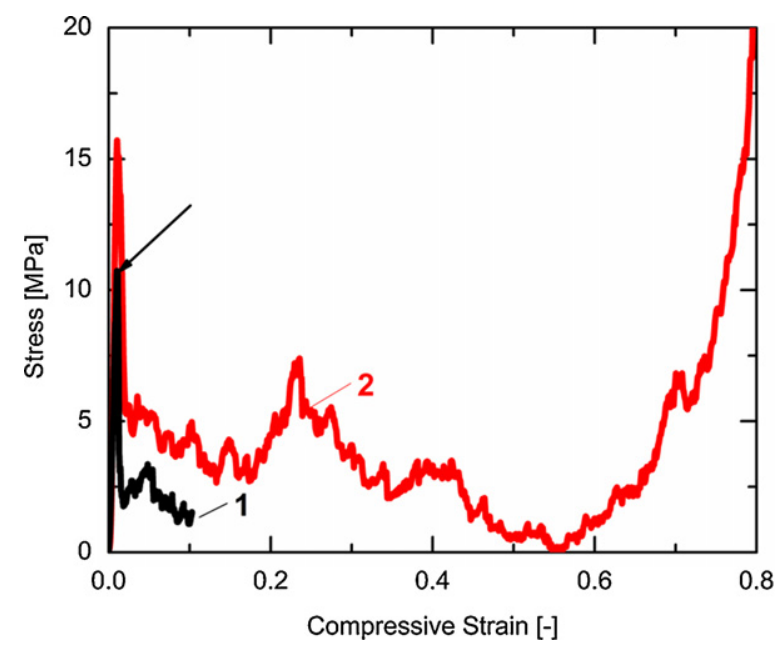

Fig. 3. Uniaxial compressive stress-strain curves for ARLloy foams 1 and 2 (64\% and $62 \%$ porosity).

The 11 and $16 \mathrm{MPa}$ peak strengths of the present ARLloy BMG foams are significantly lower than the 61-62 MPa values measured for $\mathrm{Zr}$-based BMG foams with similar porosities $p=60-63 \%$ produced by the same ECAE method [28], despite the expected

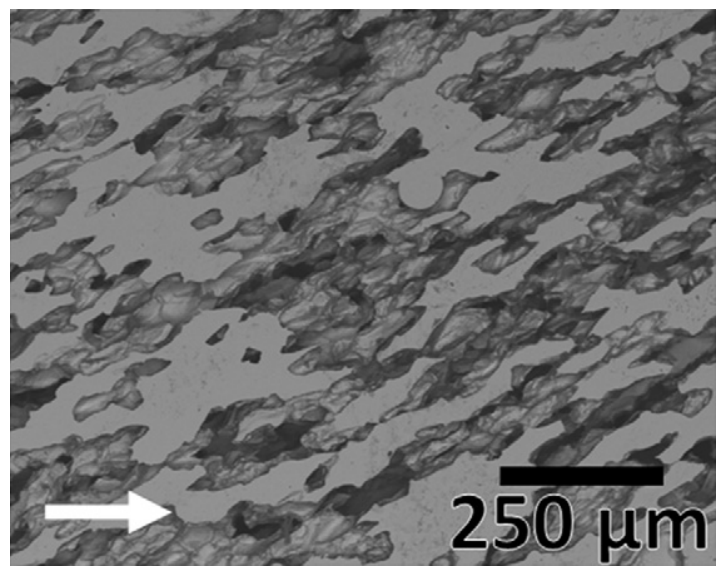

Fig. 4. SEM micrographs of surface of ARLloy foam 1 before mechanical testing, with plane of polish parallel to the extrusion direction (arrow). similarities in yield strength of the parent BMGs [2]. The Zr-based foams had fully densified BMG walls and stress-strain curves characteristic of ductile foams with significantly smaller stress drops (quantified as percentage of the applied stress) than the present Hf-based BMG foams [28]. The incomplete bonding between the ARLloy powders (Fig. 1b) is most probably responsible for the relatively low strength of the ARLloy foams. In fact, both in terms of particle bonding and peak strength, the present ARLloy foams are similar to Zr-based BMG foams created by ECAE with Ni powder as space-holders, with porosities $p=57-59$ and 6-14 MPa peak strengths [28]. Adjustments in the ECAE processing parameters (i.e., higher processing temperatures or slower extrusions rates) may improve bonding of the ARLloy powder and, in turn, increase the foam strength. However, as the low glass forming ability of ARLloy limits the processing window, other Hf-based BMG alloys with better glass forming abilities may allow for greater processing flexibility and thus lead to stronger foams [36].

In summary, we report here, for the first time, on an amorphous Hf-based BMG foam. Warm equal channel angular extrusion was used to densify a blend of amorphous Hf-based BMG and crystalline $\mathrm{W}$ powders without devitrification or formation of intermetallic phases. In a second step, the deformed $\mathrm{W}$ phase was removed electrochemically, leaving an interconnected network of aligned, elongated pores in the amorphous Hf-based matrix. Extensive ductility is achieved, as also reported for other amorphous metallic foams, when testing in compression a foam with $63 \%$ porosity in the direction of the extrusion (i.e., with the aligned pores forming a $23^{\circ}$ angle with respect to the applied stress). However, the foam compressive strength is lower than previously reported $\mathrm{Zr}$ based foams created by the same method, because of incomplete bonding between the amorphous Hf-based powders during the densification step.

\section{Acknowledgments}

MEC was supported by a National Science Foundation Graduate Research Fellowship. The authors thank Mr. Larry Jones at Ames Laboratory (Department of Energy) for BMG powder preparation; they acknowledge useful discussions with, and use of the ECAE equipment of, Prof. K. Ted Hartwig (Texas A\&M University, TAMU) as well as the experimental assistance of Mr. Robert Barber (TAMU) in operating the equipment.

\section{References}

[1] L.J. Kecskes, B.T. Edwards, R.H. Woodman, 24th US Army Sci. Con., 2004, p. 257

[2] X. Gu, T. Jiao, L.J. Kecskes, R.H. Woodman, C. Fan, K.T. Ramesh, T.C. Hunagel, J Non-Cryst. Solids 317 (2003) 112.

[3] C.A. Schuh, T.C. Hufnagel, U. Ramamurty, Acta Mater. 55 (2007) 4067.

[4] L.S. Magness Jr., Mech. Mater. 17 (1994) 147.

[5] A.L. Greer, Mater. Today 12 (2009) 14.

[6] K.M. Flores, D. Suh, R. Howell, P. Asoka-Kumar, P.A. Sterne, R.H. Dauskardt, Mater. Trans. 42 (2001) 619.

[7] E.S. Park, D.H. Kim, Met. Mater. Int. 11 (2005) 19.

[8] D.C. Hofmann, J.-Y. Suh, A. Wiest, G. Duan, M.L. Lind, M.D. Demetriou, W.L. Johnson, Nature 451 (2008) 1085.

[9] A.H. Brothers, D.C. Dunand, MRS Bull. 32 (2007) 639.

[10] A.H. Brothers, D.C. Dunand, Adv. Mater. 17 (2005) 484.

[11] A.H. Brothers, D.C. Dunand, Scripta Mater. 54 (2006) 513.

[12] A. Inoue, T. Wada, D.V. Louzguine-Luzgin, Mater. Sci. Eng. A 471 (2007) 144

[13] M.D. Demetriou, J.P. Schramm, C. Veazey, W.L. Johnson, J.C. Hanan, N.B. Phelps, Appl. Phys. Lett. 91 (2007) 161903.

[14] A.H. Brothers, D.C. Dunand, Acta Mater. 53 (2005) 4427

[15] A.H. Brothers, D.W. Prine, D.C. Dunand, Intermetallics 14 (2006) 857.

[16] T. Wada, F. Qin, X. Wang, A. Inoue, M. Yoshimura, Mater. Trans. 48 (2007) 2381

[17] T. Wada, A. Inoue, Mater. Trans. 45 (2004) 2761.

[18] T. Wada, X. Wang, H. Kimura, A. Inoue, Scripta Mater. 59 (2008) 1071.

[19] T. Wada, X. Wang, H. Kimura, A. Inoue, Mater. Lett. 63 (2009) 858.

[20] M.D. Demetriou, C. Veazey, J. Schroers, J.C. Hanan, W.L. Johnson, Mater. Sci. Eng. A 449 (2007) 863.

[21] F. Baldwin, N.V. Ravi Kumar, K. Das, A. Bandyopadhyay, Y.M. Gupta, Mater. Sci. Eng. A 477 (2008) 233. 
[22] L.J. Kecskes, S.T. Szewczyk, Mater. Res. Soc. Symp. P 806 (2004) 183.

[23] J. Schroers, Adv. Mater. 22 (2010) 1566.

[24] I. Karaman, J. Robertson, J.-T. Im, S.N. Mathaudhu, K.T. Hartwig, Z.P. Luo, Metall Mater. Trans. A 35 (2004) 247.

[25] S.N. Mathaudhu, K.T. Hartwig, I. Karaman, J. Non-Cryst. Solids 353 (2007) 185.

[26] J. Robertson, J.-.T. Im, I. Karaman, K.T. Hartwig, I.E. Anderson, J. Non-Cryst. Solids 317 (2003) 144

[27] O.N. Senkov, S.V. Senkova, J.M. Scott, D.B. Miracle, Mater. Sci. Eng. A 393 (2005) 12.

[28] M.E. Cox, S.N. Mathaudhu, K.T. Hartwig, D.C. Dunand, Metall. Mater. Trans. A 41 (2009) 1706.
[29] M.H. Lee, D.J. Sordelet, Scripta Mater. 55 (2006) 947.

[30] Y. Liu, Y. Zhu, F. Li, W. Yan, Adv. Eng. Mater. 12 (2010) 1131.

[31] M.H. Lee, D.J. Sordelet, Appl. Phys. Lett. 89 (2006) 021921.

[32] K. Qiu, B. Yu, Y. Ren, J.U. Sci. Tech. Beijing, Min., Metall. Mater. 14 (2007) 59.

[33] S.N. Mathaudhu, Ph.D. Thesis, Texas A\&M University, 2006.

[34] S.J. Oh, S.B. Kang, Mater. Sci. Eng. A 343 (2003) 107.

[35] E. Lassner, W.-D. Schubert, Tungsten, Plenum Publishers, New York, 1999.

[36] L. Zhang, E. Ma, J. Xu, Intermetallics 16 (2008) 584. 